\title{
Antioxidatic and photochemical activity of photosynthetic apparatus of spring wheat at action of Pseudomonas syringae pv. atrofaciens
}

\author{
V. Patyka, Academician of the NAAS, Doctor of Biological Sciences \\ H. Guliayeva, L. Butsenko, \\ Candidates of Biological Sciences \\ T. Shcherbyna, \\ B. Osypenko, \\ L. Pasichnyk \\ Doctor of Biological Sciences \\ Institute of Microbiology and Virology named after D.K. Zabolotny National Academy of \\ Sciences of Ukraine
}

The purpose. To study comprehensively physiological features of action of the causal organism of basal bacteriosis on state, photochemical activity of photosynthetic apparatus, and also activity of antioxidatic ferments of plants of wheat. Methods. Microbiological, physiological, biochemical, statistical. Results. Data on heightening the level of antioxidatic activity of leaves of wheat are generalized: increase of catalase and peroxidase activity of plants of spring wheat in a tillering stage, infected by the causal organism of basal bacteriosis. Inhibiting action of Pseudomonas syringae pv. atrofaciens on the photosynthetic apparatus of plants of spring wheat of grade Pecherianka - decrease of the content of pigments in leaves (chlorophyll pigment $a, b$ and carotenoids) is revealed. The method of induction of fluorescence of chlorophyll pigment displays depressing actinism of leaves that result in lowering of efficiency of dark reactions of photosynthesis. Conclusions. Becoming infected by the causal organism of basal bacteriosis P. syringae pv. atrofaciens results in increase of activity of ferments antioxidatic protection (catalase and peroxidase) for 11-th day from the beginning becoming infected, essential cutting of pigment content of leaves of the infected plants of spring wheat (chlorophyll pigment $a, b$ and carotenoids), and also in lowering of efficiency of dark phase of photosynthesis.

Key words: Triticum aestivum L., spring wheat, Pseudomonas syringae pv. atrofaciens, catalase, peroxidase, pigments, induction of fluorescence of chlorophyll pigment.

Among the grain crops, wheat occupies a leading position in the food market of Ukraine, providing the population with valuable food products, in particular bakery products. A significant part of wheat grain goes to export, replenishing the country's budget, which is especially important in the context of the current economic crisis in our country. In this regard, great importance is devoted to finding ways to increase yield and grain quality. Therefore, special attention is paid to the research of widespread bacterial diseases and their causative agents, which destroy the crop and impair its quality. One of these diseases is basal bacteriosis of wheat (the causative agent Pseudomonas syringae pv. atrofaciens), whose propagation in the EU countries is up to $15 \%$, and sometimes in favorable years, can reach $30-80 \%[9,13]$. The most negative impact at strong degree of development of disease was deterioration of the physic-technological and biochemical properties of the grain.

The purpose of research. The comprehensively investigate the physiological features of the action of the causative agent of basal bacteriosis on the state, the photochemical activity of the photosynthetic apparatus, as well as the activity of the antioxidant enzymes of the wheat plants.

Research methodology. The greenhouse experiments have been performed with Pecherianka variety spring wheat plants, with were grown on gray podzolized soil during 65-68 days to a phase of full ripeness. Artificial infection with bacterial suspension $P$. syringae pv. atrofaciens 9771 , having a density of $1 \times 10^{9}$ CFU / ml, was carried out on 7 daily plants. Scheme of experiment: 1- Control (uninfected plant); 2. - Wheat 
plants infected with $P$. syringae pv. atrofaciens. The replication of the experiment was threefold. The measurement of antioxidant enzymes activity (catalase (EC 1.11.1.6) has been performed by titerometric method and expressed in the amount of $\mathrm{O}_{2}$ resulting from the action of the enzyme for 1 min per $1 \mathrm{~g}$ of wet weight sample $\left(\mathrm{ml} \mathrm{O}_{2} \cdot \mathrm{g}^{-1} \cdot \mathrm{min}^{-1}\right)$, and peroxidase (EC I.II.I.7) - by the method of Boiarkin [1] and expressed in the conventional units per $\mathrm{mg}$ of wet weight.

Enzyme activity has been performed in after 11 days from inoculation. The pigments content of the leaves has been measured at 14 days from infection with extraction method in DMSO with followed by spectrometry [7, 11]. One week after infection have been perform the measurements of changes in the functional state of the photosynthetic apparatus. The status and activity of photosynthetic apparatus of wheat plants uninfected and infected with $P$. syringae pv. atrofaciens was investigated by biophysics of method of chlorophyll a fluorescence induction (CFI). The fluorescence induction data have been measurement by flurometer «Florotest», made in Ukraine [8]. The portable device «Florotest» is equipped with a LCD display (128 • 64 pixels) and remote optoelectronic radiation sensor of $470 \pm 15 \mathrm{~nm}$ irradiation wavelength, area irradiation of light spot is not less than $15 \mathrm{~mm}^{2}$ and light within it not less than $2.4 \mathrm{~W} / \mathrm{m} 2$. The spectral range of fluorescence measurements is within $670-800 \mathrm{~nm}$. The «Floratest» software, provided with the device performs the measured data import via computer USB-port and displays the data in tabular or graphical form [8]. Вимірювання ІФХ проводили через 7 і 12 діб після штучного ураження збудником базального бактеріозу $P$. syringae pv. atrofaciens.

The CFI measurement have been on 7th and 12th days after artificial infection with agent of basal glume rot $P$. syringae pv. atrofaciens. The resulting array have been represented in graphical form. The critical parameters CFI, there are reflection of variation in functional components of photosynthetic apparatus, have been calculated based on the data obtained $[4,5,8]$.

The parameters, which have been analyzing $F_{0}$ value - minimal fluorescence; $F_{p l}$ - parameter «plateau of fluorescence»; fluorescent quenching $(q F=(F m-F t) / F t) ; \mathrm{K}_{\mathrm{pl}}-\mathrm{Q}_{\mathrm{B}}$-amount of non-renewable complexes that do not participate in the linear electron transport, has been calculated as $\left.K_{p l}=\left(F_{p l}-F_{0}\right) /\left(F_{m}-F_{0}\right)\right) ; \mathrm{K}_{\mathrm{i}}$ - value is correlated with the intensity of process of fixation of carbon dioxide in dark reaction, that calculated as $\left(K_{i}=\left(F_{m}-F_{t}\right) / F_{m}\right)[3,4,5]$.

Statistical analysis have been performed with Statistika 8.0 applications use.

Research results. It has been found in our investigations that under influence of the causative agent of basal bacteriosis $P$. syringae pv. atrofaciens 9771 in the leaves of infected plants of Pecherianka variety spring wheat significant activity change of antioxidant ferments: increase the catalase $(23 \%)$ and peroxidase activity (in 2.2 times) (Table 1). The ratio of the enzymatic activity of catalase to peroxidase had the following dynamics: 1.63 (to control), 0.9 (to bacterial defeat). Consequently, after artificial inoculation of Pecherianka variety spring wheat plants with a causative agent of basal bacteriosis $P$. syringae pv. atrofaciens 9771 have been observed an increase in the activity of terminal oxidases in leaf tissues, and the ratio their activity decreased with move up in peroxidase activity (a week after infection).

\section{Influence of the casuative agent of basal bacteriosis $P$. syringae pv. atrofaciens on the activity of antioxidant enzymes (11 days infection)}

\begin{tabular}{|l|l|l|}
\hline \multirow{2}{*}{ Variants of experience } & Results \\
\cline { 2 - 3 } & $\begin{array}{l}\text { catalase activity } \\
\mathrm{ml} \mathrm{O}_{2} \cdot \mathrm{g}^{-1} \cdot \mathrm{min}^{-1}\end{array}$ & $\begin{array}{l}\text { peroxidase activity } \\
\Delta \mathrm{Z}_{670 \mathrm{~g}^{-1} \cdot \mathrm{C}^{-1}}\end{array}$ \\
\hline Control (without infection) & $1,73 \pm 0,08$ & $1,062 \pm 0,053$ \\
\hline $\begin{array}{l}\text { Inoculation of } P . \text { syringae pv. atrofaciens } \\
9771 \text { wheat plants }\end{array}$ & $2,13 \pm 0,10$ & $2,330 \pm 0,116$ \\
\hline
\end{tabular}

As you know, the antioxidant system is a mechanism of systemic phyto resistance, in particular, its components - catalase and peroxidase. Catalase (EC 1.11.6) and peroxidase (EC 1.11.7), as components of the antioxidant system, recycle hydrogen peroxide to water, using various compounds as reducing 
agents $[2,6,10]$. It is envisaged that catalase protects the cell from hydrogen peroxide, which is generated intracellularly, and peroxidase - causes specific intracellular oxidative processes involving peroxide, which lead to the formation of important metabolites [6, 10].

So, after 11 days afterartificial infected of plants, an increase in the enzymatic activity of the components of antioxidant defense was shown, which led to stimulation of the phytoimmunity of the experimental wheat plants, thus maintaining the homeostasis of the plant cell at an adequate level to ensure the protection of the cellular components from the destruction with free radicals and their derivatives. We have been hypothesized that in this case the metabolism is aimed at stabilizing the integrity of plant, and probably reduces support of biosynthetic processes in tissues. We have been established a decrease in the content of the main photosynthetic pigments in the leaves of experimental plants: the content of chlorophyll a decreased by $55.5 \%$, and chlorophyll $b$ - by $66.7 \%$. The content of carotenoids, which are additional pigments, and perform the protective function, decreased twice (Table 2). Consequently, such a significant reduction in the content of pigments could be due to the decrease in the level of expenditure of assimilates to biosynthetic processes under conditions of oxidative stress, and more rapid destruction of pigment complexes.

2. Influence of the casuative agent of basal bacteriosis on the content of photosynthetic pigments in leaves of Pecheryanka variety spring wheat (14 days of infection)

\begin{tabular}{|l|l|l|l|}
\hline \multirow{2}{*}{ Variants of experience } & Pigments & \multicolumn{3}{|l|}{} \\
\cline { 2 - 4 } & $\begin{array}{l}\text { chlorophyll a } \\
(\mathrm{mg} / \mathrm{g})\end{array}$ & chlorophyll $b(\mathrm{mg} / \mathrm{g})$ & carotenoids \\
\hline Control (without infection) & $0,9 \pm 0,04$ & $0,6 \pm 0,02$ & $0,2 \pm 0,01$ \\
\hline $\begin{array}{l}\text { Inoculation of } P \text {. syringae pv. atrofaciens } \\
9771 \text { wheat plants }\end{array}$ & $0,4 \pm 0,01$ & $0,2 \pm 0,01$ & $0,1 \pm 0,003$ \\
\hline
\end{tabular}

Thus, at the initial stage of the development of symptoms of basal bacteriosis - a week after infecting wheat plants with causative agent $P$. syringae pv. atrofaciens 9771 have been observed a significant increase in the enzymatic activity of antioxidant defense components - catalase and peroxidase, indicating the launch of cellular phytoimmunity mechanisms, but under these conditions, the content of the main photosynthetic pigments in the leaf blades decreased twice, which could be caused by a decrease in the level of expenditure of assimilates to biosynthetic processes, and more rapid destruction of pigment complexes under conditions of oxidative stress.

Therefore, to determine the effects of infecting the plants of wheat $P$. syringae pv. atrofaciens we investigated its influence on the separate functional sections of the photosynthetic apparatus with the biophysical method of fluorescence a induction using a portable devise «Floratest». On figure 1 shows the typical Kautsky`s inductive curves, with reflected the effect on functional components of PS II. 
The analyzing of critical parameters of CFI curves revealed an increase in nonproductive consumption of light quanta when it migrated over a pigment matrix at the beginning of the fast phase of fluorescence, (which shows a change in the parameter $F_{0}$ ) when all the reaction centers are open and the maximum excitation energy is reached to them (Table 3$)$. The minimal fluorescence $\left(F_{0}\right)$ increase has been observed on $11,4 \%$ ( 7 days after artificial infection) and on $54.9 \%$ (12 days after infection). As a result, this showing a significant reduction in the absorption efficiency of light quanta in result from to the degradation of pigment complexes, and a decrease in chlorophyll a concentration in the leaves, as evidenced by the obtained data (see Table 2), since is known to be that chlorophyll a has the ability to fluorescence and is part of the PS II. Significant growth of $\mathrm{F}_{\mathrm{pl}}$ value - by $42.0 \%$ is an indicator of blocking electronic transport in electron transport chain (ETC), and hence a decrease in the efficiency of attracting photons in the "light"
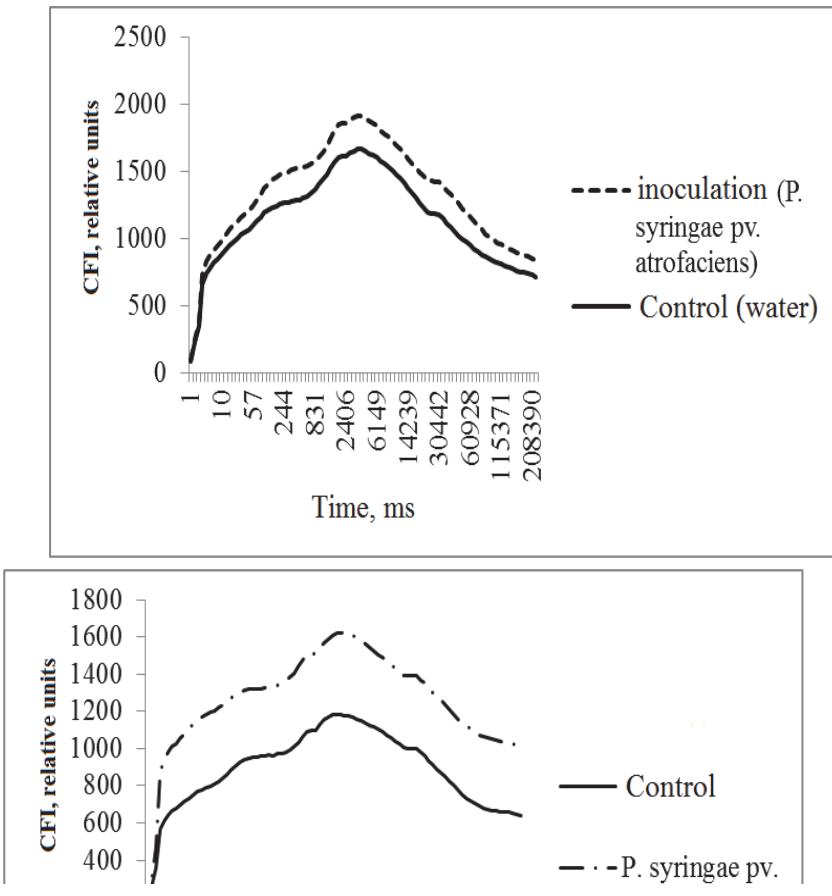

phase of photosynthesis. This is also evidenced by a six-fold increase in the $\mathrm{K}_{\mathrm{pl}}$ index in plants leaves after bacterial infected, which indicates a critical increase in the content of the amount of non-renewable $\mathrm{Q}_{\mathrm{B}}$ complexes that do not participate in the linear transport of electrons (Table 3).

3. The critical parameters CFI in leaves of Pecherynka variety wheat plant artificially infected by $P$. syringae pv. atrofaciens 9771

\begin{tabular}{|c|c|c|c|c|c|}
\hline \multirow{2}{*}{ Variants of } & \multicolumn{5}{|c|}{ Parameters } \\
\hline & $\mathrm{F}_{0}$ & $\mathrm{~F}_{\mathrm{pl}}$ & $\mathrm{K}_{\mathrm{pl}}$ & $\mathrm{qF}$ & $\mathrm{K}_{\mathrm{i}}$ \\
\hline \multicolumn{6}{|l|}{7 days after inoculation } \\
\hline Control (without infection) & 656 & 1189 & 0,58 & 1,32 & 0,57 \\
\hline $\begin{array}{l}\text { Inoculation of } P \text {. syringae pv. } \\
\text { atrofaciens } 9771 \text { wheat plants }\end{array}$ & 731 & 1456 & 0,65 & 1,28 & 0,56 \\
\hline \multicolumn{6}{|l|}{12 days after inoculation } \\
\hline Control (without infection) & 565 & 909 & 0,39 & 1,57 & 0,57 \\
\hline $\begin{array}{l}\text { Inoculation of } P \text {. syringae pv. } \\
\text { atrofaciens } 9771 \text { wheat plants }\end{array}$ & 875 & 1291 & 2,60 & 0,17 & 0,37 \\
\hline
\end{tabular}

Under these conditions, the induction coefficient (Ki), which correlated with the intensity of ribulose-1,5bisphosphate carboxylase/oxygenase activity (the main enzyme of the Calvin cycle), and usually indicated to effectiveness of the dark reactions of photosynthesis [3] - was at the control level, and on the 12th day 
of infecting, it decreased by 35\% (Table 4), which indicated to a gradual suppression of the effectiveness of dark processes of photosynthesis with increasing exposure of the causative agent of basal bacteriosis, which deepened with time. However, the level of fluorescence depends on a number of molecularbiochemical processes, the activation of which, when adapted to light, leads to a decrease in the fluorescence signal level of chlorophyll (quenching fluorescence, $q F$ ) $[5,12]$. The photochemical side of it (photochemical extinction) depends on the oxidation-reducing state of the primary electron carrier - $\mathrm{Q}_{\mathrm{A}}$, whereas not photochemical - from the level of thermal dissipation of the excitation energy. At the same time, the level of photochemical quenching can vary widely, rising with the restoration of $Q_{A}$ and decreasing with its oxidation, which controlled mainly by the level of carbon metabolism (Calvin cycle) [5]. Significant decrease of this indicator in relation to its level in control plants after a week after phytopathogenic inoculation and its deepening after 12 days infected indicates an increase in the level of oxidation of the primary carrier of photochemical energy $Q_{A}$, and hence inhibition of processes that support of electronic transport and processes in which ATP and $\mathrm{NADPH}_{2}$ is consumed.

\section{Conclusions}

Inoculation with the causative agent of basal bacteriosis $P$. syringae pv. atrofaciens leads to an increase in the activity of antioxidant enzymes - catalase and peroxidase at 11 days from the onset of infection. However, there is a significant reduction in the pigment composition of the leaves of infected plants of wheat: chlorophyll $a$, chlorophyll $b$ and carotenoids.

The investigations has showed functional disorders in photosynthetic apparatus of spring wheat plants after infected with causative agent of basal bacteriosis $P$. syringae pv. atrofaciens: a decrease in the amount of active chlorophyll involved in the transfer of electrons to the reaction centers, an increase in the number of non-reducing $\mathrm{Q}_{\mathrm{B}}$-complexes, that do not participate in the linear transport of electrons. These changes in photosynthetic apparatus are reflecting the decrease effectiveness of carbon assimilation in the dark phase of photosynthesis.

\section{Bibliography}

1. Voskresenskaia O.L. Bolshoi praktikum po bioekologii. Ch. 1: ucheb. Posobiie / O.L. Voskresenskaia. - Yoshkar-Ola, Mar. gos. Un-t, 2006.- 107 c. Russian.

2. Hazarian I.G. Osobennosti struktury i mekhanizmy deistviia peroksidazy rasteniy / I.G. Hazarian, D.M. Khushpulian, V.I. Tishkov // Uspekhi biol. khimii. - 2006.- 46.- C. 303-322. Russian.

3. Diagnostyka virusnoi infectsii smorodyny chornoi ta malyny metodom induktsii fluoreskhensii khlorofilu lystkivB / M.M. Kyryk, Yu.M. Taranukho, M.P. Taranukho, et al. // Visnyk agrarnoi nauky. - 2011. - N 10. - C. 26-28. Ukrainian.

4. Instrumentalne vyvchennia fotosyntetychnogo aparatu za dopomogoiu induktsii fluoreskhensii khlorofilu: Metodychni vkazivky dlia studentiv biologichnogo facultetu /O.V. Braion, D.Yu. Kornieiev, O.O. Sniegur, O.I. Kytaiev. - K.: Vydavnycho-polidrafichnyi tsentr «Kyivskyi universytet», 2000.- 15 s. Ukrainian.

5. Kornieiev D.Yu. Informatsionnyie vozmozhnosti metoda Информационные возможности метода induktsii fluoreskhensii khlorofilla / D.Yu. Kornieiev. - Kiev: Alterpres, 2002. -191 s. Russian.

6. Miroshnichenko O. S. Biogenesis, physiological role, and properties of catalase / O. S. Miroshnichenko // Biopolym. Cell. -1992. -8, N 6. - C.3-25.

7. Pastushenko L.T. Serological group of phytopathogenic bacteria of the Pseudomonas genus / L.T. Pastushenko, I.D. Simonovich // Mikrobiolohichnyi zhurnal. -1979. - 41, N 4. - P330-339. Russian.

8. Portatyvnyi fluorometr «Floratest»: nastanova z ekspluatatsii. - Instytut Kibernetyky im. V. M. Hlushkova NAN Ukrainy, 2013. - 24 s. Ukrainian.

9. Fitopatohenni bakterii. Bakterialni khvoroby roslyn: monograph / R.I. Hvozdiak, L.A. Pasichnyk, L.M.Yakovleva [et al.]; red. V. P. Patyka - K.: TOV «NVP «Interservis», 2011. - 444 s. Ukrainian.

10. Bolwell G.P. Mechanisms for the generation of reactive oxygen species in plant defense-broad perspective / G.P. Bolwell, P. Wojtaszek // Physiol. Mol. Plant Pathol. - 1997. - 51. - P. 347-366. 
11. Hisox J.D. The method for the extraction of chlorofill from leaf tissue whithout maceration / J.D. Hisox, R.J. Israelstam // Can. J. Bot. - 1979.-V. 57, N 12. - P. 1332-1334.

12. Horton $P$. Regulation of light harvesting in green plants. Indication by nonphotochemical quenching of chlorophyll fluorescence P. /Horton, A. Ruban, R.G. Walters // Plant Physiol. -1994. -Vol.106, N 2.P.415-420.

13. Patyka V.P. Phytopathogenic bacteria in the system of modern agriculture / V.P. Patyka, L.A. Pasichnyk // Mikrobiolohichnyi zhurnal.- 2014.- 76, N 1.- P. 21-26. 